\title{
Production, dispersal and dormancy of seeds of Albizia procera (Roxb.) Benth., a woody weed of pastures in Puerto Rico ${ }^{1,2}$
}

\author{
Jesús Danilo Chinea-Rivera ${ }^{3}$
}

\begin{abstract}
Several biological properties of Albizia procera, a woody weed of pastures in Puerto Rico are described in this study. This species is reproductively mature after approximately three years. Medium sized trees growing in the open can produce 3,500 pods in one year. Most of the pods and seeds fall within the extent of the crowns. The first $6 \mathrm{~cm}$ of soil under a 15-year-old A. procera stand had a seed bank of 315 seed per $\mathrm{m}^{2}$. Seeds experimentaliy buried at $2.5 \mathrm{~cm}$ under the surface decay at an exponential rate of 0.33 seeds per year with a half-life of $2.1 \mathrm{yr}$. This study discusses implications of these biological properties for pasture management.
\end{abstract}

Key words: woody weed, legume trees, seed bank, seed dispersal, exotic

\section{RESUMEN}

Producción, dispersión y latencia de semillas de Albizia procera (Roxb.) Benth., una maleza arbórea de pastos en Puerto Rico

Se describen características biológicas de Albizia procera, un árbol común en pastos de Puerto Rico, mejor conocido por acacia blanca, dormilón o dañafinca. Esta especie alcanza su madurez reproductiva a los tres años aproximadamente. Los árboles de tamaño mediano en lugares abiertos pueden producir hasta 3,500 vainas en un año. Las vainas pueden contener de seis a 12 semillas. El viento puede dispersar las vainas y las semillas pero la mayoría de éstas caen debajo de las copas de los árboles. Los primeros 6 $\mathrm{cm}$ de suelo de un rodal de $A$. procera de unos 15 años de edad contenia un banco de semillas de $\mathbf{3 1 5}$ semillas por metro cuadrado. Semillas enterradas experimentalmente a $2.5 \mathrm{~cm}$ de la superficie desaparecieron a una velocidad exponencial de $\mathbf{0 . 3 3}$ semilias por año, con una media vida de 2.1 años. En aquellos casos en que esta especie no sea deseable se sugiere que se elimine del terreno tan pronto sea identificada. Se recomienda precaución al arar un terreno que haya estado expuesto a la llegada de gran número de semillas ya que éstas pueden sobrevivir enterradas por varios años y se pueden establecer rápidamente luego de arar. Si hay un gran número de ár-

'Submitted to the Editorial Board 15 February 1994.

"Financial support for this study came from McIntire-Stennis grants to Dr. Peter L. Marks at the Field of Ecology and Systematics, Cornell University. Bolivar Pagán and Javier Llano helped in field sampling. The Agricultural Experiment Station at Rio Piedras and the Botanical Garden of the University of Puerto Rico provided experimental sites. The USDA Forest Service International Institute of 'Tropical Forestry provided office space and much logistic support.

3Department of Natural Resources and Environmental Sciences, W503 Turner Hall, 1102 S. Goodwin Ave., Uxbana, IL 61801, e-mail: jdchinea@ux1.eso.uiuc.edu. 
boles establecidos se recomienda podar o tumbar los mismos durante la época seca para que sirvan de suplemento alimenticio al ganado; esto se debe hacer antes de que maduren las semillas.

\section{INTRODUCTION}

The increasing number of successfully invading non-native species have attracted the attention of ecologists in recent years (Drake et al., 1989; Groves and Burdon, 1986; Groves and di Castri, 1991; MacDonald et al., 1986; Mooney and Drake, 1986). Ecologists have searched for the causes for their success by studying characteristics of the habitat and the species that make them prone to invasions. Once a non-native species has been introduced, its successful establishment depends on its capacity to produce propagules in its new environment, to disperse its seeds, and to remain dormant long enough until the conditions for its establishment and growth are met. This study addresses several aspects of the seed biology of Albizia procera that are critical for its success as an invader.

A. procera is a member of the subfamily Mimosoideae of the Leguminosae family. It is native to India, South East Asia, the Philippines, Southern China, Papua New Guinea, Melanesia, and Northern Australia (Parrotta, 1987). It is a fast growing tree reaching more than $20 \mathrm{~m}$ in height and $70 \mathrm{~cm}$ in diameter at breast height (dbh) (Little and Wadsworth, 1964). In its native range it grows on alluvial soils, savanna vegetation, and even in swampy conditions (Parrotta, 1987). In Puerto Rico it is mostly found in the moist northern half of the island along roadsides, abandoned fields, and pastures (Francis and Liogier, 1991). Today it is one of the most troublesome and widespread woody weeds on the Island (Chinea-Rivera, 1992; Francis and Liogier, 1991; Liu, 1990).

In Puerto Rico this species flowers from August to October and its fruits ripen from January to June. Eight to twelve seeds are produced in dry flat pods. The small, flat and elliptical seeds can amount to 24,000 per kg (Parrotta, 1987). Germination of seeds may occur readily on the ground and may be facilitated by hot water treatment (Halos and Fabian, 1981) or by mechanical means (Von Carlowitz, 1986). In its native range, seedlings can survive under moderate shade. If left unweeded, seedlings can reach $15 \mathrm{~cm}$ in height by the end of the first year and $3.5 \mathrm{~m}$ by the end of the fourth year (Venkataramany, 1968). In Puerto Rico, seedlings released from seven months of suppression by grasses grew up to $4.1 \mathrm{~cm}$ in dbh and $4 \mathrm{~m}$ in height during the following 15 months (Chinea-Rivera, 1992). However, trees growing on plantations elsewhere may grow at less than half the above rate (Parrotta, 1987). 
A. procera was introduced to Puerto Rico in 1924 for ornamental purposes. Later it was grown on plantations for charcoal production (Little and Wadsworth, 1964). In 1957, J. Marrero ${ }^{4}$ reported the invasion of pastures by this species in Puerto Rico.

The objectives of this study were 1) to determine the minimum size (and age) to reproductive maturity, 2) to quantify the production of seeds by mature trees, 3 ) to describe the seed shadows of reproductive trees, and 4) to quantify the persistence of seeds in the soil.

\section{MATERIALS AND METHODS}

Reproductive maturity

The minimum size to reproductive maturity of this species was determined in closed stands of different ages at two sites, one in Gurabo and another in Río Piedras. These stands were selected because there was little competition between trees. At each stand the dbh of the smallest tree in reproductive stage was measured. Visual estimates of the quantity of pods on these trees were recorded.

Seed dispersal

For a description of the seed shadow (the distribution of dispersed seeds away from the trees) several sets of three $1 \mathrm{~m}^{2}$ plots were located at different distances on the west side of two isolated fruiting trees at the Agricultural Experiment Station at Río Piedras. In this location the main wind direction is from the east to northeast. The study was initiated in mid-April, about the middle of the seed dispersal season. All the pods present in the plots were counted and removed at the outset. Ten days later the pods that had dispersed into the plots were counted. At every plot a distinction was made between open and closed pods, and as to whether the pods fell in groups attached to their fruiting branches (clusters) or as single pods. A week later a tree was sampled again and a further distinction between viable seeds (fully developed seeds) and non-viable seeds (seeds with no embryo or covered with fungal hyphae) was made. The number of seeds per pod and the proportion of viable to non-viable seeds per pod were calculated.

Seed longevity

To determine the presence of buried seeds, soil samples were obtained from a nearly pure stand about 15 years old. The samples were located along a W-shaped transect formed of four $25-\mathrm{m}$-long sections.

${ }^{-M e m o}$ at the USDA Forest Service, International Institute of Tropical Forestry. 
Within each section five random locations were selected for a total of 20 samples. At each location all above-ground vegetation was removed and a $10 \times 10 \mathrm{~cm}$ wooden frame was positioned on the ground to mark the area to be sampled. Before removing the soil all the seeds present on the soil surface were collected. Then the first $3 \mathrm{~cm}$ of soil was removed within the frame. Samples were collected from the soil between 3 and $6 \mathrm{~cm}$ in one randomly chosen location among each section of the transect. The soil samples were sieved in flushing water the same day of sampling to recover the buried seeds.

To determine the longevity of soil-buried seeds, we used the following procedure. Thirty-four groups of 50 fresh seeds were buried with autoclaved soil inside fiberglass mesh bags between 2.5 and $5.0 \mathrm{~cm}$ under the soil surface. Six or seven replicate bags, selected at random, were removed at five time intervals: $42,99,164,376$, and 711 days after burial. To recover the remaining seeds, we sieved the contents of each bag after sampling and then tested for viability. Seeds were mechanically scarified, then allowed to germinate in watered petri dishes in a shade house for a week.

Mean viability of recovered seeds for all time intervals ranged from 99 to $100 \%$. Therefore, only the number of recovered seeds is reported. The Roberts equation of seed decay: $S=S_{0} \times e^{-t h}$, where $S=$ number of seeds at time $t, S_{0}=$ initial number of seeds, $\mathrm{g}=$ decay rate, and $\mathrm{t}=$ time (Roberts, 1981) was used to calculate the decay rate and half-life of these seeds. Data were analyzed by a linear regression procedure of the log-transformed number of recovered seeds at the time of sampling.

\section{RESULTS}

\section{Seed production}

The smallest fruiting trees found growing in open conditions were as small as $11 \mathrm{~cm}$ dbh and had an estimate of 1,000 pods. At a dbh increment rate as high as $4 \mathrm{~cm} / \mathrm{yr}$ (Chinea-Rivera, 1992) the age of first reproduction may be as early as the third year. However, trees $11 \mathrm{~cm}$ $\mathrm{dbh}$ growing in dense stands or in the shade of larger trees produced only 0 to 40 pods. It appeared that intraspecific competition in these crowded trees reduced their dbh increments, so their age at reproductive maturity must be older than the third year.

Figure 1 shows the relationship between number of pods produced and dbh of two size groups of $A$. procera. Results across locations indicate that young but reproductively mature trees from 11 to $17 \mathrm{~cm}$ in $\mathrm{dbh}$, growing in the open, produced an average of 480 pods per tree. Medium-sized trees from 17 to $24 \mathrm{~cm}$ in dbh produced an average of 1,315 pods per tree. 


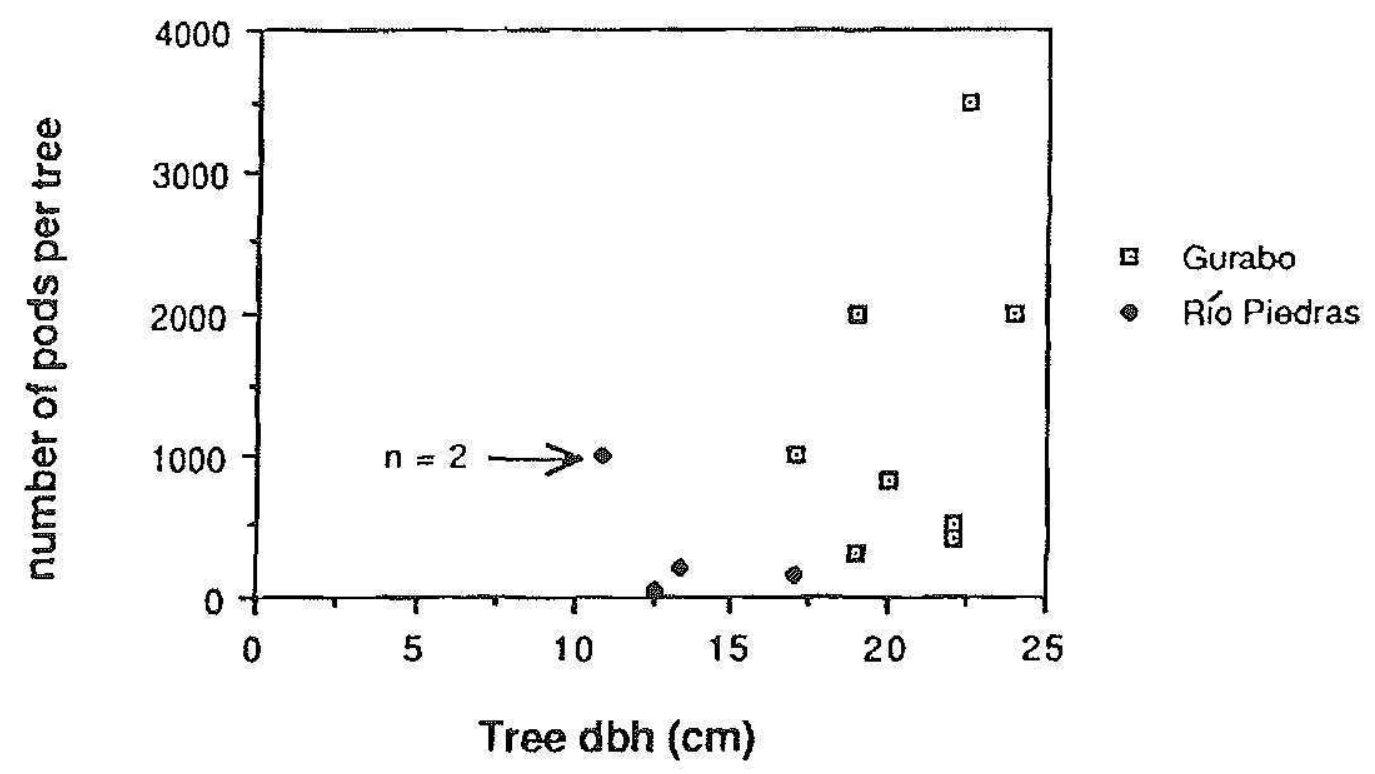

FIGURE 1. Number of pods produced by isolated trees in one year as a function of stem dbh. Smaller stems were sampled in an inactive pasture in the Agricultural Experiment Station in Río Piedras; the larger stems were sampled in an active pasture in Gurabo.

Seed dispersal

A larger number of pods fell under the crown of these trees than beyond (Figures 2 and 3). Most pods fell in clusters of 2 to 42 pods. However, the percentage of single pods increased with distance from the parent tree from $33 \%$ below the crowns to $76 \%$ at $20 \mathrm{~m}$ away from the stems. This difference may be larger because branches may lose pods when they hit the ground.

A. procera produces from 6 to 12 seeds per pod (Little and Wadsworth, 1964). Assuming that pods carried the same number of seeds to the plots, from 51 to 102 seeds $/ \mathrm{m}^{2} /$ day fell under the crowns, whereas only 5 to $10 \mathrm{seeds} / \mathrm{m}^{2} /$ day fell at a distance of $20 \mathrm{~m}$. Six days later a tree was sampled. It had dropped 6.5 to 13 seeds $/ \mathrm{m}^{2} /$ day under its crown and 0.8 to $1.7 \mathrm{seeds} / \mathrm{m}^{2} /$ day beyond its crown. Although the proportion of seeds under the crown to seeds beyond the crown remained similar (10:1 and 8:1 for the first and second sampling periods, respectively), the total number of dispersed seeds at the last period was about 6 to 8 times less than during the previous period.

Seed bank

There were an average of 90 seeds $/ \mathrm{m}^{2}( \pm 55 \mathrm{SE})$ on the soil surface, 215 seeds $/ \mathrm{m}^{2}( \pm 69 \mathrm{SE})$ between 0 and $3 \mathrm{~cm}$, and $100 \mathrm{seeds} / \mathrm{m}^{2}( \pm 70 \mathrm{SE})$ 


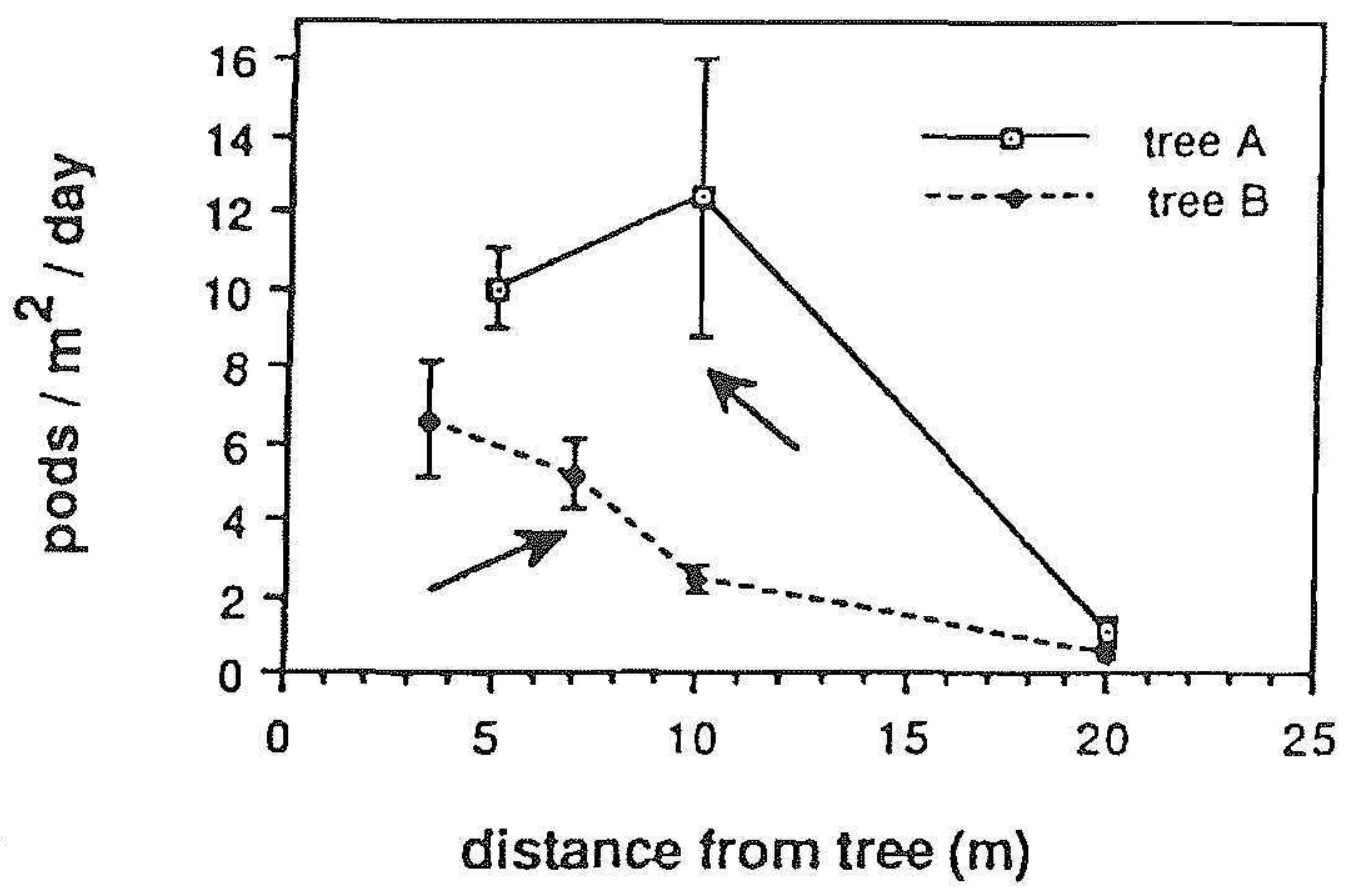

FiguRe 2. Number of pods collected in groups of three $1 \mathrm{~m}^{2}$ samples located at different distances from the stems of two isolated trees growing in an inactive pasture in Río Piedras. Arrows indicate the maximum extension of the crowns, bars are a standard error of the mean.

between 3 and $6 \mathrm{~cm}$ of the soil surface in a 15-year-old stand at Rio Piedras. Therefore, the soil at this location stored 4.05 million seeds/ha $( \pm 1.13 \mathrm{SE})$ within the first $6 \mathrm{~cm}$ of the surface.

There was a large initial decrease in viable seeds during the first six weeks of burial, a $56 \%$ reduction. Seeds were reduced to $78 \%$ of the initial amount after two years. The exponential model (Figure 4) indicated a decay rate of 0.33 seeds per yr or a half-life of 2.1 yr for A procera seeds.

A. procera seedlings were found inside the fiberglass bags at all sampling periods. Thus, many of the seeds disappeared because of germination rather than predation or disease. Soil pathogens or fauna may have helped the natural scarification process before germination.

\section{DISCUSSION}

Isolated $A$. procera trees start to reproduce early in their life-cycle. This reproductive capability may have adaptive value in cases where young tree populations are exposed to large mortality because it will assure further reproduction if at least some fields are fallowed or abandoned for a brief period. In these situations, trees of recently attained reproductive maturity are only 4 to $5 \mathrm{~m}$ tall; therefore, their capacity to 

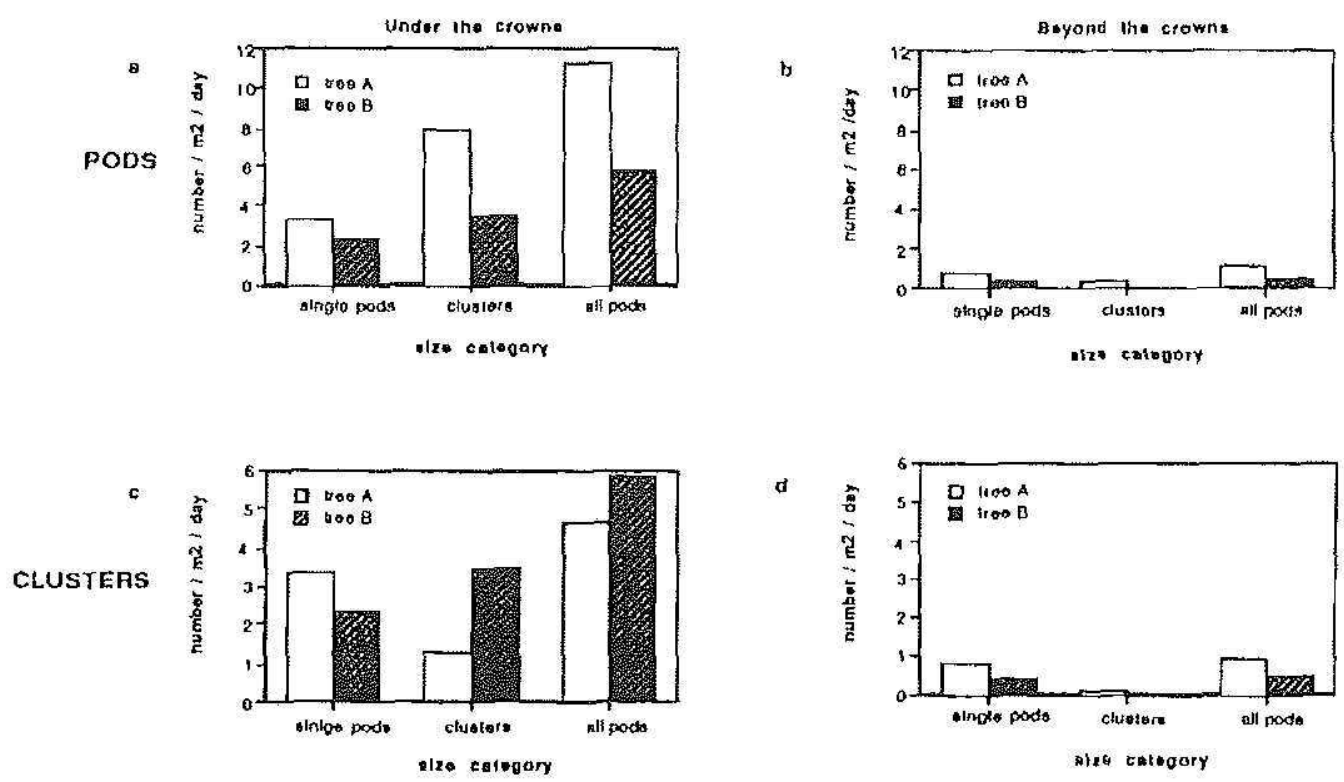

FIGURE 3. Fall rate of pods as a function of cluster size category, and relative fall location.

disperse seeds is limited, but they can provide for dispersal in time by accumulating a pool of dormant seeds in the soil.

As is the case for other wind dispersed plants (Harper, 1977; Silvertown, 1982), most $A$. procera pods were dispersed at short distances from the parent trees (Figure 2). However, wind may be more effective for long distance dispersal than these pod shadows suggest, especially in a treeless landscape with low herbaceous cover (pastures) because wind speeds may be high near the ground (Welch et al., 1990).

In this study only the dispersal of A. procera seeds by wind has been examined. However, small proportions of fallen pods or pods still attached to the trees, with signs of seed predation, were observed at several locations. This observation suggests seed predation and dispersal by small vertebrates. There is also the possibility that large domestic grazers may act as seed dispersal agents. Cattle were observed feeding on immature pods when these were made available to them. It has been reported that cattle may pass seeds of other legume species (Enterolobium cyclocarpum) intact through their digestive tracts (Janzen, 1982). However, A. procera seeds or seedlings were never observed in cattle dung throughout the course of this study.

A. procera is also capable of dispersing in time. It can produce a large pool of dormant seeds as shallow in the soil profile as 0 to $6 \mathrm{~cm}$ deep, lasting for more than two years. Seeds buried deeper would be expected to remain dormant for a longer period (Froud-Williams, 1987). Buried seeds may be brought to the surface by agricultural practices 


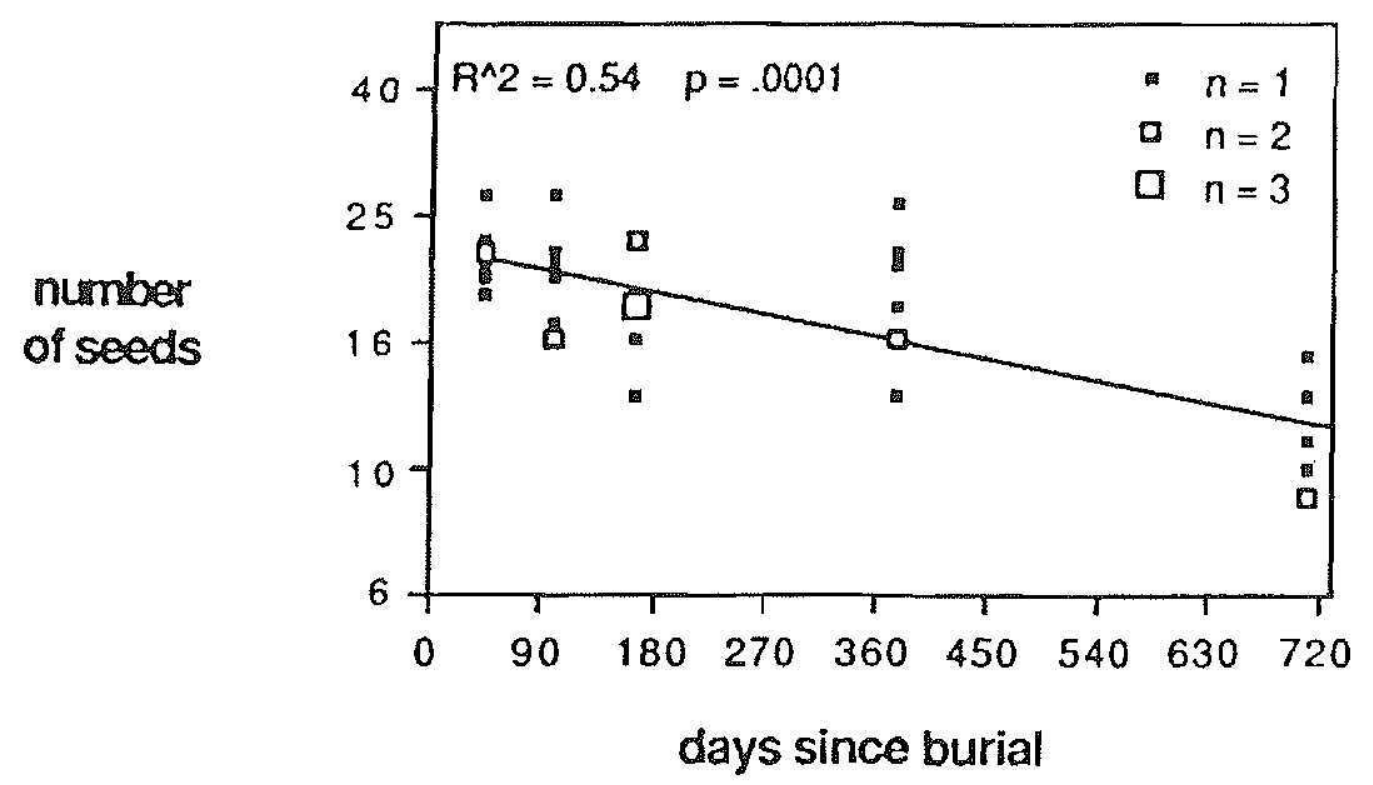

Figune 4. Number of seeds recovered from fiberglass bags buried at 2.5 to $5.0 \mathrm{~cm}$ deep. Each bag was buried with 50 seeds. Results for each bag removed from the soil are presented; the first four times are based on seven replicates; the last time is based on six replicates.

thus giving them an early start when nutrients and light are abundant, and competition from surrounding vegetation may be at its lowest (Mortimer, 1984).

The knowledge of these seed characteristics of $A$. procera can be useful to farmers in the area. If this species is considered a nuisance, then trees should be eliminated from the fields and the edges of fields as soon as they are spotted, or at least before they mature their first seeds. If seeds have reached the fields in considerable numbers, plowing may enhance their establishment from the pool of buried seeds. In such circumstances, a crop which produces a fast and dense cover should be preferred so that $A$. procera seedlings will encounter a highly competitive environment.

\section{LITERATURE CITED}

Chinea Rivera, J. D., 1992. Invasion dynamics of the exotic legume tree Albizia procera (Roxb.) Benth in Puerto Rico. Ph.D. Dissertation, Cornell University, Ithaca, NY.

Drake, J. A., H. A. Mooney, F. di Castri, R. H. Groves, F. J. Kruger, M. Rejmanek and M. Williamson, 1989. Biological invasions: a global perspective. John Wiley \& Sons.

Francis, J. K. and H. A. Liogier, 1991. Naturalized exotic tree species in Puerto Rico. USDA Forest Service, Southern Forest Experimental Station, General Technical Report SO-82.

Froud-Williams, R. J., 1987. Survival and fate of weed seed populations: interactions with cultural practice. 1987 British Crop Protection Conference - Weeds: 707-718. 
Groves, R. H. and J. J. Burdon, 1986. Ecology of biological invasions. Cambridge University Press.

Croves, R. H. and F. di Castri, 1991. Biogeography of Mediterranean invasions. Cambridge University Press, NY.

Halos, S, C. and C. I. Fabian, 1981. A quick, simple method of improving the gernination of stored akleng-parang (Albizia procera (Roxb.) Benth.I seeds. Syluatrop Philippine Forestry Research Journal. 6:85-90.

Harper, J. L., 1977. Population biology of plants. Academic Press, NY.

Janzen, D., 1982. Differential seed survival and passage rates in cows and horses, surrogate Pleistocene dispersal agents. Oikos 38:150-6.

Little, E. L. and F. H. Wadsworth, 1964. Common trees of Puerto Rico and the Virgin Islands. USDA Forest Service, Agricultural Handbook \#249.

Liu, L. C., 1990. Chemical control of Albizia and mesquite in two selected pastures in southern Puerto Rico. J. Agric. Uniu. P.R. 74:433-9.

Macdonald, I. A. W., F. J. Kruger and A. A. Ferrar, 1986. The ecology and management of biological invasions in southern Africa. Proceedings of the National Synthesis Symposium on the ecology of biological invasions. Oxford University Press, Cape Town.

Mooney, H. A. and J. A. Drake, 1986. Ecology of biological invasions of North America and Hawaii. Ecological Studies 58, Springer-Verlag, NY.

Mortimer, A. M., 1984. Population ecology and weed science. p. 363-388. In: Dirzo, R. and J. Sarukhán (eds.) Perspectives in plant population ecology. Sinauer Associates Inc., Massachusetts.

Parrotta, J. A, 1987. Albizia procera (Roxb.) Benth. Silvics Manual of tropical trees. USDA Forest Service, Institute of Tropical Forestry, SO-ITF-SM-6.

Roberts, H. A., 1981. Seed banks in soils. Advances in Applied Biology 6:1-55.

Silvertown, J. W., 1982. Introduction to plant population ecology. Longman, NY.

Venkataramany, P., 1968. Silviculture of genus Albizia and species. Silviculture of Indian trees, No. 22. Delhi: Government of India.

Von Carlowitz, P. G., 1986. Multipurpose tree and shrub seed directory. International Council for Research in Agroforestry, Nairobi, Kenya.

Welch, D., G. R. Millex and C. J. Legg, 1990. Plant dispersal in moorlands and heathlands. p. 115-132. In: Bunce, R. G. H., and D. C. Howard (eds.) Plant dispersal in agricultural habitats. Belhaven Press, NY. 